\title{
Analysis of the influence of low-power HeNe laser on the healing of skin wounds in diabetic and non-diabetic rats ${ }^{1}$
}

\author{
Análise da influência do laser de baixa potência (HeNe) na cicatrização de feridas \\ cutâneas em ratos diabéticos e não diabéticos
}

\author{
Paulo de Tarso Camillo de Carvalho² ${ }^{2}$ Nilton Mazzer ${ }^{3}$, Filipe Abdalla dos Reis ${ }^{4}$, Ana Carulina Guimarães Belchior ${ }^{4}$, \\ Iandara Schettert Silva ${ }^{5}$ \\ 1. Work performed at the Department of Biomechanics, Medicine and Rehabilitation of the Locomotor Apparatus, Faculty of Medicine, \\ University of São Paulo (USP), Ribeirão Preto - SP Brazil. \\ 2. PhD, Department of Physiotherapy, University for State and Pantanal Region Development (UNIDERP), Campo Grande - MS. Brazil. \\ 3. Associate Professor, Department of Biomechanics, Medicine and Rehabilitation of the Locomotor Apparatus, Faculty of Medicine, USP, \\ Ribeirão Preto - SP. Brazil. \\ 4. Assistant Professor, Department of Physiotherapy, UNIDERP, Campo Grande - MS. Brazil. \\ 5. PhD, Department of Veterinary Medicine, UNIDERP, Campo Grande - MS. Brazil.
}

\begin{abstract}
Purpose: To study the influence of HeNe laser irradiation on the collagen percentage in surgically-induced skin wounds in rats with and without alloxan-induced diabetes, by morphometric analysis of collagen fibers. Methods: 48 male Wistar rats were used, divided into groups: laser-treated diabetic (group 1); untreated diabetic (group 2); treated non-diabetic (group 3); and untreated non-diabetic (group 4). For groups 1 and 2, diabetes was induced by intravenous injection of alloxan (2,4,5,6-tetraoxypyrimidine; 5,6-dioxyuracil; Sigma), into the dorsal vein of the penis, at a rate of $0.1 \mathrm{ml}$ of solution per $100 \mathrm{~g}$ of body weight. A wound was made on the back of all the animals. Groups 1 and 3 were treated with HeNe laser $\left(4 \mathrm{~J} / \mathrm{cm}^{2}\right)$ for $60 \mathrm{~s}$. One animal from each group was sacrificed on the $3^{\text {rd }}, 7^{\text {th }}$ and $14^{\text {th }}$ days after wounding. Samples were taken, embedded in paraffin, stained with hematoxylin-eosin and Masson's trichrome, and morphometrically analyzed using the Imagelab software. The percentages of collagen fibers were determined from the samples from the euthanasia animals. The data were treated statistically using analysis of variance (ANOVA) and the Student $t$ and Kruskal-Wallis tests. The significance level was set at 0.05 or $5 \%$. Results: The results obtained from the samples taken on the third, seventh and fourteenth days after wounding demonstrated that the laser-treated group presented a statistically significant $(p<0.05)$ greater mean quantity of collagen fibers than in the non-treated group, both for diabetic rats $(p=0.0104)$ and for non-diabetic rats $(\mathrm{p}=0.039)$. Conclusion: The low-power laser $(632.8 \mathrm{~nm})$ was shown to be capable of influencing the collagen percentage in skin wounds by increasing the mean quantity of collagen fibers, both for the diabetic and for the non-diabetic group.
\end{abstract}

Key words: Laser Therapy, Low-Level. Wound Healing. Collagen. Rats.

\section{RESUMO}

Objetivo: Estudar, comparativamente, através de análises morfométricas das fibras colágenas, a influência da irradiação com laser HeNe no percentual de colágeno de lesões cutâneas induzidas em ratos diabéticos aloxânico e não diabéticos. Métodos: Foram utilizados 48 ratos Wistar, machos sendo estes divididos em grupos: Grupo 1 diabético tratado com laser, Grupo 2 diabético não-tratado, Grupo 3 não-diabético tratado e Grupo 4 não-diabéticos não-tratados. Nos grupos 1 e 2 diabetes foi induzido por injeção intravenosa (veia dorsal do pênis de Aloxana (2, 4, 5, 6 - Tetraoxypyrimidina; 5 - 6 Dioxyuracila) SIGMA, $0.1 \mathrm{ml}$ de solução a cada 100 g. de peso corporal. Todos os animais foram submetidos a uma lesão no dorso e os Grupos 1 e 3, foram tratados com laser HeNe com dosagem de $4 \mathrm{~J} / \mathrm{cm}^{2}$ por $36 \mathrm{~s}$. Um animal de cada grupo sofreu eutanásia no $3^{\circ}, 7^{\circ}$ e 14 dias após a lesão e retiradas as amostras que foram emblocadas em parafina, coradas com $H . E$., Tricrômico de Masson e a analisadas morfométricamente pelo software IMAGELAB . Os dados resultantes foram tratados estatisticamente pela análise de variância (ANOVA), e pelos testes t e Kruskal-Wallis fixou-se em 0,05 ou 5\% (a $£$ 0,05) o nível de rejeição da hipótese de nulidade. Resultados: Os resultados obtidos das amostras retiradas aos $3^{\circ}, 7^{\circ}$ e 14 dias após a lesão, demonstram que o grupo tratado com laser apresentou média de fibras colágenas maiore estatisticamente significante $(\mathrm{p}<0.05)$, em relação ao grupo não-tratado, tanto para diabéticos ( $\mathrm{p}=0.0104)$, como não-diabéticos ( $\mathrm{p}=0.039)$. Conclusão: O laser de baixa potência $(632,8 \mathrm{~nm})$ se mostrou capaz de influenciar o percentual de colágeno em feridas cutâneas, aumentando a média de fibras colágenas, tanto para o grupo diabético como no não-diabético.

Descritores: Terapia a Laser de Baixa Potência. Cicatrização de Feridas. Colágeno. Ratos. 


\section{Introduction}

Healing is a complex process and has attracted the attention of researchers over the years, particularly regarding factors that delay or hinder it. The most important repair failures are those that occur in the initial stages. These lead to accentuation of edema, reduced vascular proliferation and decreased quantities of cell elements such as leukocytes, macrophages and fibroblasts ${ }^{1}$.

Such alterations in these events give rise to low collagen synthesis and also contribute towards increased risk of infections among diabetic patients. Diabetes mellitus is a syndrome of multiple etiologies, characterized by the absence of insulin. It is estimated that there are more than 150 million people with diabetes in the world, and in Brazil the number is close to 12 million $^{2}$.

Currently, studies are being conducted to seek new therapeutic methods for resolving or minimizing failures of tissue repair presented by patients with diabetes mellitus. Low-level laser therapy techniques are particularly being studied. The therapeutic effects of laser on different types of biological tissue are extensive. These have been demonstrated by in vitro and in vivo studies, and include trophic-regenerative, anti-inflammatory and analgesic effects. Among such studies, those that have demonstrated gains in local microcirculation ${ }^{3}$, the lymphatic system ${ }^{4}$ and collagen synthesis in fibroblasts ${ }^{1,5}$ can be highlighted. The present study was motivated by the need to investigate the therapeutic results from laser radiation in relation to factors that interfere in the healing process in skin wounds in diabetic patients and in the morbidity that they can cause. The objective of the present study was to determine the influence of low-power (632.8 nm) laser on the collagen percentage in skin wounds in diabetic and non-diabetic rats.

\section{Methods}

The sample consisted initially of 120 adult male rats (Rattus norvegicus albinus) of the Wistar-Adolfo LutzUFMS line, from the animal colony, Federal University of Mato Grosso do Sul (UFMS), Campo Grande, State of Mato Grosso do Sul, Brazil. Their mean body weight was $295.0 \pm$ $17 \mathrm{~g}$. The animals were confined in cages of $0.15 \mathrm{~m}^{2}$ in area, with four animals per cage. Their confinement conditions consisted of ten to twelve-hour light periods, controlled temperature and humidity maintained by air conditioning, minimal noise, and the provision of solid chow and water ad libitum. They were observed for two days before their use in the experiment. All the experimental procedures adopted were in line with the norms of the Brazilian College of Animal Experimentation (COBEA) and the norms for teaching-scientific practices relating to animal vivisection (Law 6638 of May 8, 1979).

\section{Experimental groups}

Twenty-four of the 120 animals were chosen at random to make up the group of non-diabetic animals and the 96 remaining animals had diabetes induced using alloxan. This division resulted in two experimental groups: diabetic and non-diabetic rats. These groups were divided into four subgroups and received the following names: subgroup 1 , treated diabetic rats (TD); subgroup 2, untreated diabetic rats (UD); subgroup 3, treated non-diabetic rats (TND); and subgroup 4, untreated non-diabetic rats (UND). All these subgroups were further divided again into three, seven and 14-day groups.

\section{Induction of diabetes using alloxan}

The 96 rats that had diabetes induced using alloxan were kept without food for the preceding 24 hours, because rats become more susceptible to diabetes under these conditions. Anesthesia was administered by means of intraperitoneal injection of ketamine (7\%) and xylazine (0.3\%) at a ratio of 2:1, using $0.2 \mathrm{ml} / 100 \mathrm{~g}$ of body weight. The animals were then placed in dorsal decubitus, ready to receive an intravenous injection of alloxan $(2,4,5,6$ tetraoxypyrimidine; 5,6-dioxyuracil; SIGMA), into the dorsal vein of the penis (Figure 1). A stock solution of $50 \mathrm{mg}$ of alloxan per $0.8 \mathrm{ml}$ of physiological serum was prepared for the alloxan injection at this time. The injection was administered in a proportion of $0.1 \mathrm{ml}$ of solution per 100 grams of body weight, thus resulting in a final dose of 62.5 mg of alloxan per $\mathrm{kg}$ of body weight. The animals were treated with glucose solution (10\%) during the first six hours after the injection, to prevent convulsions and death, which are common in the hypoglycemic stage. After 24 hours, the glucose was removed from the water.



FIGURE 1 - Graph comparing the means, standard deviations and statistical crossings resulting from morphometric analysis of collagen percentages in the subgroups: TD (treated diabetic) and UD (untreated diabetic); TND (treated non-diabetic) and UND (untreated nondiabetic)

The following glycemia monitoring scheme was used to confirm whether diabetes was present: the glycemia level was measured before diabetes induction and 72 hours thereafter, and the animals that did not present values greater than or equal to $250 \mathrm{mg}$ per deciliter of blood (mg/dl) were discarded. The glycemia level was measured again on the fifth day after the treatment, to confirm whether the animal continued to be diabetic. Finally, the glycemia level was measured on the day of sacrificing, to determine 
whether any reversion of the diabetes had occurred. The measurements were made by removing blood from the tail vein and placing one drop on Advantage $\mathrm{II}^{\circledR}$ reactive tape. The glycemia level was read using the Glucometer ${ }^{\circledR}$ apparatus, resulting in a mean glycemia level of $310.0 \pm 60$ $\mathrm{mg} / \mathrm{dl}$. Thirty-eight of the 96 animals that were injected with the diabetes-inducing drug did not develop hyperglycemia, and seven died due to hypoglycemia during the first 24 hours of the hypoglycemic stage. Over the next 48 hours, 23 died due to hyperglycemia. Four animals died during the experiment and were replaced.

\section{Skin wound production}

The surgical procedures for producing the skin wound were carried out under dissociative anesthetic consisting of $10 \%$ ketamine together with $2 \%$ xylazine, at doses of 1 mg per $100 \mathrm{~g}$ and $2 \mathrm{mg}$ per $100 \mathrm{~g}$ of live weight, respectively, by means of intramuscular injection. The skin on the dorsal region of all the animals was shaved before surgery, using an aseptic technique, in the area between the infrascapular line and the tail. A plastic template of $1.5 \mathrm{~cm}$ in diameter was utilized to mark out the incision area with a dermographic pen, and the dimensions were confirmed using a pachymeter. The surgical incision was made with a scalpel in the marked area, using the mid-dorsal line as a reference, and it included the epidermis, dermis and dorsal fascia. The depth of the skin wound was standardized by reference to viewing of the muscle plane.

After the surgical operation, laser irradiation was applied to the treated groups. The animals were then placed in clean cages (four animals per cage), with free access to water and suitable chow. Two animals died during the anesthetic procedure and were substituted so that the study could be continued.

\section{Laser therapy application}

Each animal in the treated subgroups received HeNe laser application at an energy density of $4 \mathrm{~J} / \mathrm{cm}^{2}$, over an area of 3 $\mathrm{cm}^{2}$, thus resulting in a calculated laser application of 60 seconds per wound. For this, the HeNe laser was used at a maximum continuous power level of $5 \mathrm{~mW}$, with a wavelength of $632.8 \mathrm{~nm}$ and laser beam area of $0.025 \mathrm{~cm}^{2}$. (Table 1 )

The radiation was applied shortly after the surgical procedure and was maintained by means of daily applications. The untreated subgroups were taken to be comparative controls for the histological analysis. One animal from each group was submitted to euthanasia on the third, seventh and fourteenth days after the surgery, by means of inhalation of ethyl ether, and samples were removed for morphometric analysis.

\section{Histological procedures}

The specimens for histological analysis were fixed in $10 \%$ formalin for 24 hours. They were then embedded in paraffin and sections of thickness $5 \mu \mathrm{m}$ were cut. Pairs of slides underwent a staining process: one with hematoxylineosin and the other with Masson's trichrome.

\section{Morphometric analysis}

Morphometric analysis was performed on the slides, by means of image digitization and computational analysis using a specific image processing and analysis program (Imagelab). To quantify the areas representing collagen, five fields observed using an Axiolab microscope (Carl Zeiss, 20x lens) were digitized. The microscope was coupled to an image-capturing Sanyo digital active BLC camera, and this was connected to a Pentium IV $1.2 \mathrm{GHz}$ microcomputer equipped with a video board. Each digitized field had horizontal resolution of 640 points and vertical resolution of 80 points, with 24 color bits (median of 16 colors). The digitized fields corresponded to real image areas of $395 \mu$ wide by $300 \mu$ high.

All the images were digitized before the quantification process, thereby standardizing the microscope light intensity and condenser height. The collagen areas were separated in the image, using the color distribution as the discriminating parameter. The same color interval was used for each quantified image, in order to separate the DNA to be quantified. The standardized color interval was defined empirically at the start of the experiment. A color band was adjusted by trial and error, until the representative areas of collagen had been separated in the image. The same interval was then used to identify the collagen to be quantified in all the digitized fields. In a subsequent step, the area occupied and the quantity of light absorbed by the collagen was calculated for each of the fields.

\section{Statistical analysis}

The results obtained were subjected to statistical analysis of variance (ANOVA) according to two criteria, with four replications. The Kruskal-Wallis or Student $t$ test for paired samples was applied. The nature of the variables studied or the variability of the means was considered using the Biostatistics software. The significance level was set at 0.05 or $5 \%$.

TABLE 1 - Laser treatment parameters

\begin{tabular}{lllllll}
$\begin{array}{l}\text { Type of } \\
\text { Laser }\end{array}$ & Power & Wavelength & Spot size & $\begin{array}{l}\text { Energy } \\
\text { density }\end{array}$ & $\begin{array}{l}\text { Power } \\
\text { density }\end{array}$ & Time \\
\hline $\mathrm{HeNe}$ & $5 \times 10-3$ & $632,8 \mathrm{~nm}$ & $0,025 \mathrm{~cm}^{2}$ & $4 \mathrm{~J} / \mathrm{cm}^{2}$ & $0,2 \mathrm{~W} / \mathrm{cm}^{2}$ & $20 / \mathrm{seg}^{2}$ \\
\hline
\end{tabular}




\section{Results}

The collagen samples from the diabetic groups (TD and UD) and non-diabetic groups (TND and UND) were analyzed and the sample removal times (three, seven, and fourteen days after wounding) were also compared according to mean collagen percentages. The means resulting from the morphometric analyses of collagen percentages were subjected to statistical analysis. The statistical analysis showed that there were significant differences ( $p=0.0155)$ in the collagen means between the diabetic groups (treated and untreated) and the non-diabetic groups (treated and untreated). In both cases, the treated groups presented higher means than did the untreated groups (Figure 1). There was a significant difference between the means for the samples from the diabetic group (TD and UD), collected on the third, seventh and fourteenth days. The mean for the samples collected on the third day was lower than for the other days, by means of the ANOVA test ( $p=0.0104)$ and Student's t test for paired samples (Table $2)$. The mean collagen percentage in the diabetic group after 14 days was significantly greater than after three days. There was a significant difference between the means for the collagen samples from the non-diabetic group (TND and
UND), collected on the third, seventh and fourteenth days. The mean collagen percentage for the samples collected on the third day group was lower than for the other days, by means of the ANOVA test $(\mathrm{p}=0.039)$ and Student's t test for paired samples (Table 2). Comparison of the means for the treated group samples (TD and TND) collected on the third, seventh and fourteenth days, by means of the variance comparison test, showed a significant difference between the collection days $(p=0.006)$. There was also a significant difference by utilizing the Kruskal-Wallis test ( $p=0.0081)$. The mean collagen percentage for the samples from the third day was lower than in the other subgroups (Table 3).

The results from the ANOVA test $(p=0.0001)$ and Student's t test for paired samples, between the means for the untreated group sample (UD and UND), collected on the third, seventh and fourteenth days, are also shown in Table 3. These data showed that there were differences between all the results, and that the mean collagen percentage for the three day subgroup samples was less than those of the seventh and fourteenth-day subgroups, and that the mean for the seventhday subgroup was also lower than that of the fourteenth-day subgroup (Figures 2, 3 and 4).

TABLE 2 - Comparison of means and probabilities for the collagen samples in the diabetic subgroups (TD and UD) and non-diabetic subgroups (TND and UND), collected on the third, seventh and fourteenth days

\begin{tabular}{|c|c|c|c|c|c|c|}
\hline \multirow{2}{*}{$\begin{array}{l}\text { Subgroup } \\
\text { Diabetic }\end{array}$} & \multicolumn{2}{|c|}{3 days vs. 7 days } & \multicolumn{2}{|c|}{3 days vs. 14 days } & \multicolumn{2}{|c|}{7 days vs. 14 days } \\
\hline & 21.58 & 27.19 & 21.58 & 30.77 & 27.19 & 30.77 \\
\hline & \multicolumn{2}{|c|}{$p=0.0116$} & \multicolumn{2}{|c|}{$\mathrm{p}<0.00001$} & \multicolumn{2}{|c|}{$p=0.0503$} \\
\hline \multirow[t]{2}{*}{ Non-diabetic } & 22.10 & 28.48 & 22.10 & 31.78 & 28.48 & 31.78 \\
\hline & \multicolumn{2}{|c|}{$p=0.0209$} & \multicolumn{2}{|c|}{$p=0.0011$} & \multicolumn{2}{|c|}{$\mathrm{p}=0.2099$} \\
\hline
\end{tabular}

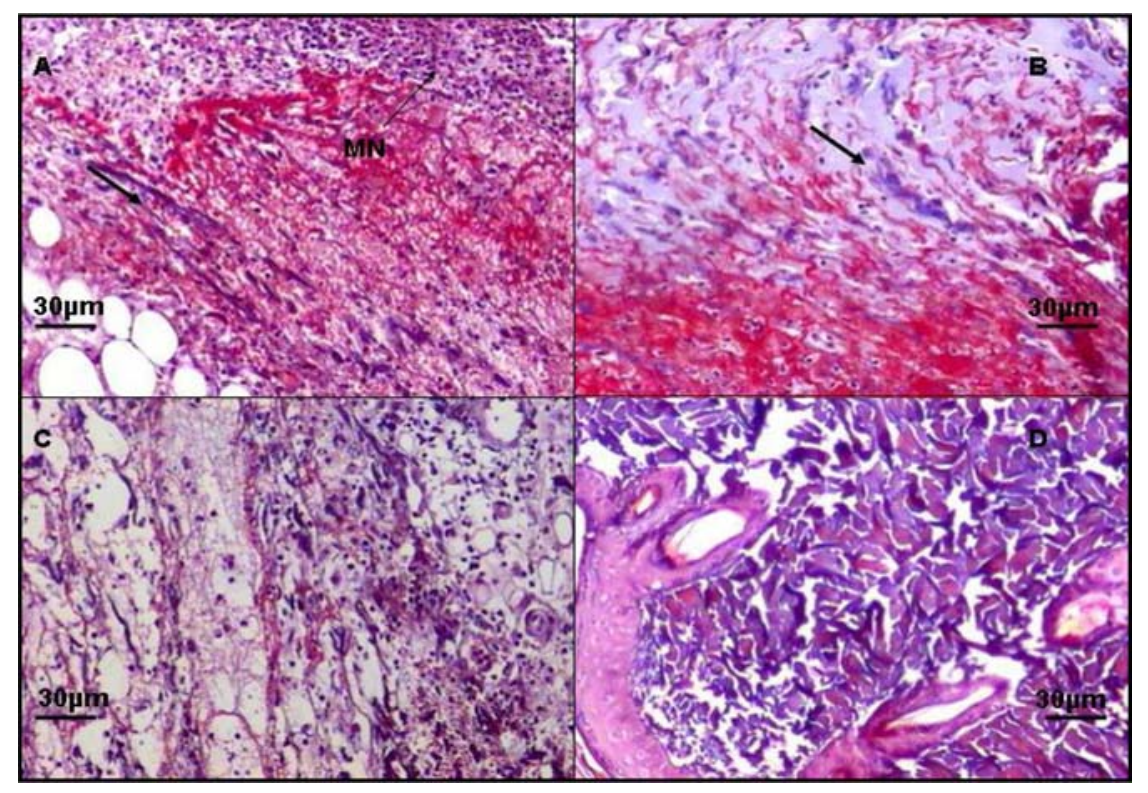

FIGURE 2 - Montage of photomicrographs after three days, showing collagen fiber concentrations in the different groups: (A) few collagen fibers (arrow), with presence of mononuclear cells (MN) in subgroup TD; (B) collagen fiber contraction showing resistance of fibers stained blue (arrow), in subgroup TND; (C) scarcity of fibers in subgroup UD; and (D) fibers in the organization stage, in subgroup UND. Masson's trichrome, 200X 
TABLE 3 - Comparison of means and probabilities for the collagen samples in the treated subgroups (TD and TND) and untreated subgroups (UD in UND), collected on the third, seventh and fourteenth days

\begin{tabular}{|c|c|c|c|c|c|c|}
\hline \multirow{2}{*}{$\frac{\text { Subgroup }}{\text { Treated }}$} & \multicolumn{2}{|c|}{3 days vs. 7 days } & \multicolumn{2}{|c|}{3 days vs. 14 days } & \multicolumn{2}{|c|}{7 days vs. 14 days } \\
\hline & 24.22 & 30.23 & 24.22 & 33,06 & 30,23 & 33,06 \\
\hline & \multicolumn{2}{|c|}{$\mathrm{p}=0.0403$} & \multicolumn{2}{|c|}{$\mathrm{p}=0.0024$} & \multicolumn{2}{|c|}{$\mathrm{p}=0.3222$} \\
\hline \multirow[t]{2}{*}{ Untreated } & 24.14 & 18.94 & 24.14 & 28,48 & 18,94 & 28,48 \\
\hline & \multicolumn{2}{|c|}{$\mathrm{p}=0.0047$} & \multicolumn{2}{|c|}{$\mathrm{p}<0.00001$} & \multicolumn{2}{|c|}{$\mathrm{p}=0.0158$} \\
\hline
\end{tabular}

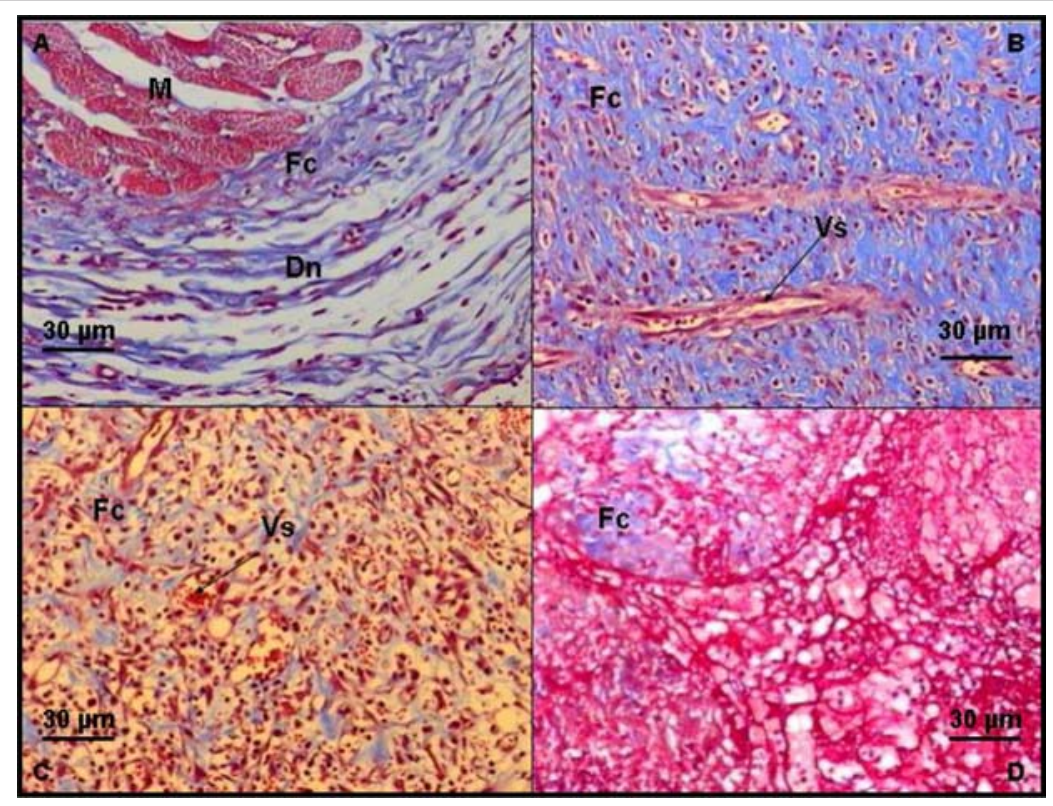

FIGURE 3 - Montage of photomicrographs after seven days, showing collagen fiber concentrations in the different subgroups: (A) increased numbers of collagen fibers (Fc) with characteristic dense unmodeled appearance (Dn) and showing muscle tissue (M), in subgroup TD; (B) fibers stained blue (Fc) and vessel neoformation (VS), in subgroup TND; (C) scarcity of fibers (FC) and endothelial proliferation (Vs), in subgroup UND; (D) fibers in the organization stage (Fc), in subgroup UD. Masson's trichrome 200X

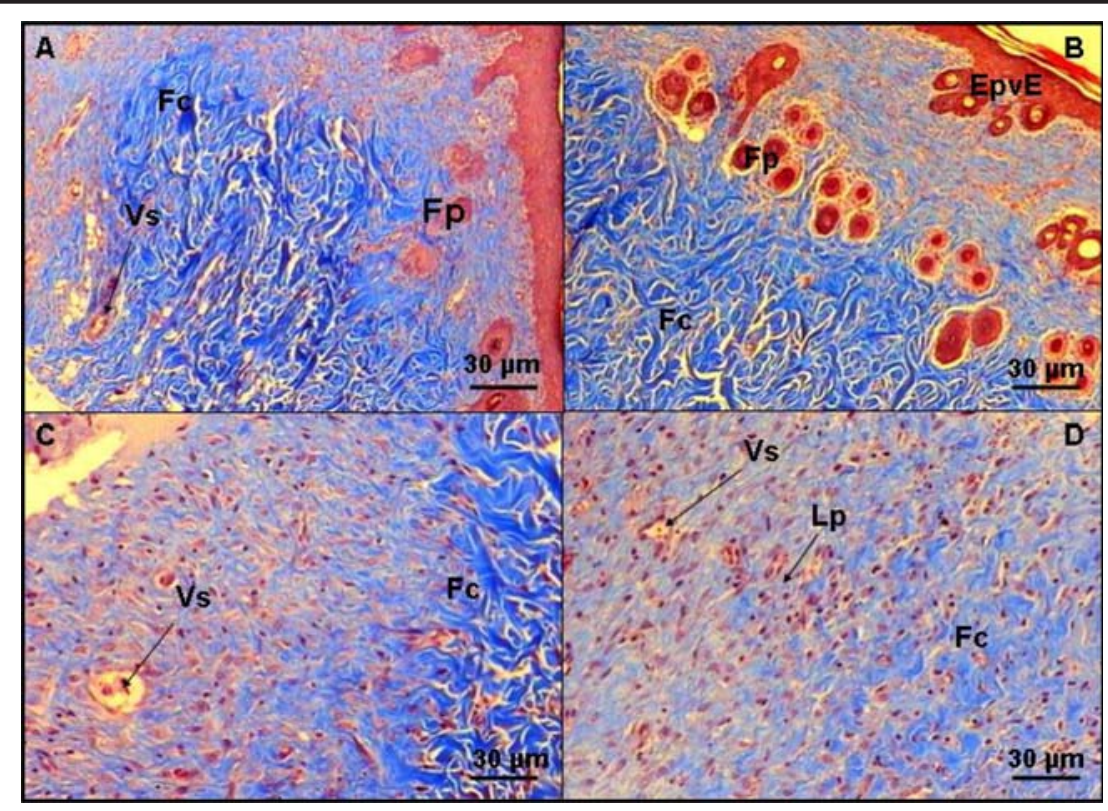

FIGURE 4 - Montage of photomicrographs after fourteenth days showing collagen fiber concentrations in the different groups: (A) increased numbers of collagen fibers ( $\mathrm{Fc}$ ) and presence all of pilose follicle (Fp) and blood vessels (Vs arrow) subgroup TD; (B) observe collagenous fiber concentration stained blue (Fc), pilose follicle (Fp) and regenerated covering epithelium (EpvE) subgroup TND; (C) observe scarcity of fibers (Fc) and blood vessels (VS) subgroup UND (D) observe organized fibers with denser characteristics (Fc), blood vessels (VS area) and lymphoplasmocytary cells (Lp) subgroup UD. Masson’s trichrome, 200X 


\section{Discussion}

The proposal to analyze tissue repair in diabetic rats was based on the vast literature that reports the healing difficulties caused by diabetes mellitus ${ }^{6,7,8}$. Insulin deficiency syndrome can be obtained experimentally in rats by surgery or by administering diabetes-inducing drugs such as alloxan and streptozotocin. This has been confirmed by several authors. ${ }^{6,8,9}$

Rats with diabetes induced by alloxan produce less granulation tissue than do normal rats. The scars on such animals show weak mechanical resistance, and these alterations have been attributed to biochemical alterations in the wound, caused by insulin deficiency syndrome. ${ }^{6}$

The animals in the present study showed a response rate to endovenous alloxan administration of $55.2 \%$. This is similar to the results obtained in a recent study ${ }^{10}$ in which the animals were considered diabetic when their insulin level was greater than or equal to $120 \mathrm{mg} / \mathrm{dl}$. In the present study, the animals with glycemia greater than or equal to $250 \mathrm{mg} / \mathrm{dl}$ were considered to be diabetic. Analysis of the results obtained three days after wound induction indicated lower collagen percentages in the control subgroups, i.e. the subgroups not given laser treatment presented lower and statistically significant mean collagen percentages, in comparison with the treated subgroups. These results corroborate studies 5, 8, 11, 12, 13 in which laser treatment accelerated the wound healing process, with increased production of collagen, a substance that is essential for wound repair. When the results obtained from the control subgroups were analyzed and compared, it was observed that the treated non-diabetic subgroup presented a higher and statistically significant collagen fiber percentage, in comparison with the untreated diabetic subgroup. These results confirm studies ${ }^{15,16,17}$ in which diabetic rats presented delayed repair. These differences were observed mainly during fibroblast differentiation, which precedes collagen formation. Statistical analysis of the data obtained from the laser-treated subgroups on the third day after wounding showed significant differences in mean collagen percentages between these groups. Thus, laser therapy was able to maintain equal conditions between the subgroups at this repair stage, even when comparing diabetic and nondiabetic animals.

The literature ${ }^{14,15}$ shows that during the first days of healing, the repair events are directed towards preventing subsequent blood loss (hemostasis), and formation of a fibrin plug that supplies the preliminary matrix for the subsequent processes, in which the platelets adhere to the collagen in the perivascular space. This contact activates the platelets, thereby releasing platelet factors that accelerate the migration and proliferation of the principal cell type in the healing process: fibroblasts. The results obtained on the seventh day after wounding showed increased collagen fiber percentages, in comparison with the third day. It was found that the control subgroups presented lower mean collagen than did the treated subgroups, but this finding was only statistically significant in relation to the means for the untreated non-diabetic subgroup. This suggests that the action of the HeNe laser accelerated the granulation and formation of fibroblastic tissue, thus confirming the abovementioned results.

At this point (seven days after wounding), the extra cellular matrix began to be replaced by stronger and more flexible conjunctive tissue, with macrophage activation and production of specific growth factors. Studies have shown that diabetes mellitus interferes incisively with this repair stage. However, no significant difference in mean collagen percentages between the diabetic and non-diabetic groups was detected in the present study. We believe that this alteration in healing response may be explained by the action of the laser, as reported by several researchers. ${ }^{6,8,11,12}$

Analysis of the results from the fourteenth days after wounding showed increased mean collagen percentages in comparison with the seventh day. However, only the nondiabetic group presented a statistically significant result. The relationships between the subgroups were maintained, with a slightly higher mean obtained for the treated nondiabetic group. The difference between mean collagen percentages was also maintained between the untreated subgroups, and the mean remained higher in the untreated non-diabetic subgroup. Comparing the fourteenth and seventh days, the development of collagen decelerated in the treated subgroups, in comparison with their untreated controls. This deceleration in collagen growth in the treated subgroups was due to their maturation stage. It has been reported in the literature that cell proliferation decreases at this stage, with a gradual reduction in the number and size of the fibroblasts. Concomitantly, there is a slow increase in the flexible resistance of the wound, bearing in mind that the collagen fibers undergo greater interlinking that increases their thickness and compaction. ${ }^{14,15,16}$

Our results confirm those of Ikeuchi ${ }^{17}$, who reported that, fourteen days after surgery, animals irradiated by HeNe laser at an energy density of $3.6 \mathrm{~J} / \mathrm{cm}^{2}$ presented scar tissue that was more mature, with most of the collagen fibers arranged in parallel, in comparison with the control groups. Furthermore, it has been reported ${ }^{7,8,9}$ that the untreated diabetic subgroup remained at a much lower level of healing than for the other subgroups at all stages studied (3, 7 and 14 days). From the foregoing, the evidence indicates that low-power was capable of increasing the mean collagen percentage, both in the diabetic and non-diabetic groups. These findings are corroborated by other studies ${ }^{7,8,9,14,18}$ that demonstrate the efficiency of low-power laser for accelerating the healing process in diabetic and non-diabetic animals, by increasing the quantity of fibroblasts and collagen fibers.

\section{Conclusion}

Low-power (632.8 nm) laser was shown to be capable of influencing the collagen percentage in skin wounds, by increasing the mean quantity of collagen fibers, both for the diabetic and for the non-diabetic group. 


\section{References}

1. Carvalho PTC, Mazzer N, Barbieri CH. Morphometric analysis of the percentage of collagen and number of macrophages highlighted by immunohistochemistry, in cutaneous wounds in diabetic and non-diabetic rats treated through HeNe laser. Lasers Med Sci. 2003; 18(Suppl 2): S26-6.

2. Lerco MM, Spadella CT, Machado JLM. Caracterização de um modelo experimental de Diabetes Mellitus, induzido pela aloxana em ratos: estudo clínico e laboratorial. Acta Cir Bras. 2003; 18(2): 132-42.

3. Maier M, Haina D, Landthaler M. Effect of low energy laser on the growth and regeneration of capillaries. Laser Ther. 1993; 5 (2): 79-87.

4. Lievens PC. The effect of IR laser irradiation on the vasomotricity of the lymphatic system. Lasers Med Sci. 1991; 6: 189-91.

5. Reddy GK, Stehno-Bittel L, Enwemeka CS. Laser photostimulation of collagen production in healing rabbit Achilles tendons. Lasers Surg Med. 1998; 22: 281-7

6. Reddy GK. Comparison of the photostimulatory effects of visible He-Ne and infrared Ga-As lasers on healing impaired diabetic rat wounds. Lasers Surg Med. 2003; 33(5): 344-51.

7. Schindl A, Schindl M, Pernerstorfer-Schoen H, Schindl L. Low intensity laser therapy in wound healing: a review with special respect to diabetic angiopathies. Acta Chir Aust. 2001, 33(3):132-7.

8. Stadler I, Lanzafame RJ, Evans R, Narayan V, Dailey B, Buehner N, Naim JO. 830-nm irradiation increases the wound tensile strength in a diabetic murine model. Lasers Surg Med. 2001;28 (3):220-6.

9. Wei-Yu C, Naim JO, Lanzafame RJ. Effects of photostimulation on wound healing in diabetic mice. Lasers Surg Med. 1997; 20 (1):56-63.

10. Whelan HT, Buchmann EV, Dhokalia A, Kane MP, Whelan NT, Wong-Riley MT, Eells JT, Gould LJ, Hammamieh R, Das R, Jett M. Effect of NASA lightemitting diode irradiation on molecular changes for wound healing in diabetic mice. J Clin Laser Med Surg. 2003; 21(2):67-74.

11. Calderon IMP. Modelo experimental em ratas para estudo do binômio diabete e gravidez [Dissertação]. Universidade Estadual Paulista - Faculdade de Medicina de Botucatu; 1988.

12. Kana J S, Hutschenreiter G, Haina D, Waidelich W. Effect of low-power density laser radiation on healing of open skin wounds in rats. Arch. Surg. 1981;116: 293-6,

13. Al-Watban F, Andres B. Polychromatic LED therapy in burn healing of non-diabetic and diabetic rats. J. Clin Laser Med Surg. 2003;21(5): 249-58,

14. Byrnes KR, Barna L, Chenault VM, Waynant RW, $\underline{\text { Ilev }}$ IK, Longo L, Miracco C, Johnson B, Anders JJ. Photobiomodulation improves cutaneous wound healing in an animal model of type II diabetes. Photomed Laser Surg. 2004;22(4):281-90.

15. Clark R A F. Cutaneous tissue repair: basic biologic considerations I. J Am Acad Dermatol. 1985;13:701-25.

16. Martin P. Wound healing aiming for perfect skin regeneration. Science. 1997; 276 (4): 75-81.

17. Woodruff LD, Bounkeo J M, Brannon W M, Dawes KS, Barham CD, Waddell D L, Enwemeka CS. The efficacy of laser therapy in wound repair: a meta-analysis of the literature. Photomed Laser Surg. 2004; 22 (3): 241- 7.

18. Ikeuchi S, Ohsaka F, Asanami S, Nomoto T. Effects of low power He-Ne laser on the healing of full-thickness skin defects. Laser Dent. 1989; 2: 85-9.

\section{Correspondence:}

Paulo de Tarso Camillo de Carvalho

Rua Abricó do Para, 146

79032-423 Campo Grande-MS Brazil

ptpaulo@terra.com.br
Conflict of interest: none Financial source: Manoel de Barros Foundation

Received: December 12, 2005

Review: January 17, 2006

Accepted: February 08, 2006

\section{How to cite this article:}

Carvalho PTC, Mazzer N, Reis FA, Belchior ACG, Silva IS. Analysis of the influence of low-power HeNe laser on the healing of skin wounds in diabetic and non-diabetic rats. Acta Cir Bras. [serial on the Internet] 2006 May-June;21(3). Available from URL: http://www.scielo.br/acb 